\title{
LOACH EMBRYOS PROOXIDANT-ANTIOXIDANT STATUS UNDER THE INFLUENCE OF AMIDE DERIVATIVES OF 1,4-NAPHTHOQUINONE
}

\author{
A. O. BEZKOROVAYNYJ ${ }^{1,2}$, A. R. ZYN ${ }^{2}$, N. P. HARASYM ${ }^{1}$, J. T. LEN $N^{2,3}$, \\ O. M. FIGURKA ${ }^{3}$, D. I. SANAGURSKY ${ }^{1}$ \\ ${ }^{1}$ Ivan Franko National University of Lviv, Ukraine; \\ ${ }^{2}$ Lviv Expert Center of Scientific Researches Ministry of Internal Affairs of Ukraine; \\ ${ }^{3}$ National University "Lviv Polytechnica", Ukraine; \\ e-mail: andriy.bezkorovajnyj@gmail.com
}

The mechanisms of disorders in cell functions induced by 1,4-naphthoquinone amide derivatives are not clarified yet. The article is dedicated to the study of features of these substances influence on loach Misgurnus fossilis L. embryos pro/antioxidant homeostasis during early embryogenesis. The aim of this work was to study the effect of 2-chloro-3-hydroxy-1,4-naphthoquinone, 2-chloro-3-(3-oxo-3-(piperidine1-yl)propylamine)-1,4-naphthoquinone (FO-1), 2-chloro-3-(3-(morpholine-4-yl)-3-oxopropylamine)-1,4naphthoquinone (FO-2 at concentrations of $10^{-3}, 10^{-5}, 10^{-7} \mathrm{M}$ on the content of TBA-reactive substances ( $a$ byproduct of lipid peroxidation) and the activities of superoxide dismutase and catalase in loach embryos. It was established that 1,4-naphthoquinone amide derivatives and 2-chloro-3-hydroxy-1,4-naphthoquinone decreased the content of lipid peroxidation products in embryo cells in a dose-dependent manner. The investigated compounds cause an increase in superoxide dismutase and catalase activities compared with the control value. The results of the two-factor ANOVA test indicate that 2-chloro-3-hydroxy-1,4-naphthoquinone and 1,4-naphthoquinone amide derivatives (FO-1, FO-2) have predominant influence on the TBA-reactive substances content and superoxide dismutase activity. However, the time of loach embryos development has a more pronounced effect on catalase activity than the studied 1,4-naphthoquinone derivatives.

Key words: loach embryos, 1,4-naphthoquinone amide derivatives, lipid peroxidation, superoxide dismutase, catalase.

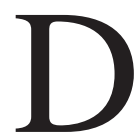
erivatives of 1,4-naphthoquinone are widely used in medicine and veterinary as bacteriostatic, bactericidal and fungicidal preparations. These substances are characterized by a broad spectrum of biological activities, such as antiinflammatory, antiviral and anti-allergic. 1,4-Naphthoquinone derivatives are used for treatment of respiratory diseases [1, 2].

Currently, quinoid compounds are considered to be the second largest class of antineoplastic agents, some of which are at various stages of preclinical and clinical trials [1, 2].

The literature has described the effects of amide derivatives of 1,4-naphthoquinone on various cancer cell lines: KB (oral cancer), NCI-H187 (small cell lung cancer), MCF-7 (breast cancer) and Vero cell line (monkey kidney epithelium) [1-3]. The results of these studies demonstrate that amide derivatives are able to stop cancer cells growing and have a low cytotoxicity to the pseudonormal Vero cell line $[1,3]$. It was found that one of the targets for biological actions of these derivatives is the active site of topoisomerase IIa (an enzyme that affects the DNA topology) [1, 2].

The mechanisms through which naphthoquinones can cause these effects are complicated $[4,5]$. It is known that quinones, having a high reduction potential, can participate in a redox cycle through their semiquinone radicals that results in formation of reactive oxygen species (ROS), including superoxide, hydrogen peroxide and, particularly, hydroxyl radical. The formation of these molecules may lead to oxidative stress in cell due to damage to cellular macromolecules, such as lipids, proteins, and DNA $[4,5]$.

On the other hand, quinones act as acceptors in the Michael reaction, and cellular damage can be caused by alkylation of important cellular proteins and/or DNA [4]. 
<smiles>O=C1C(O)=C(Cl)C(=O)c2ccccc21</smiles>

2-chloro-3-hydroxy-1,4-naphthoquinone

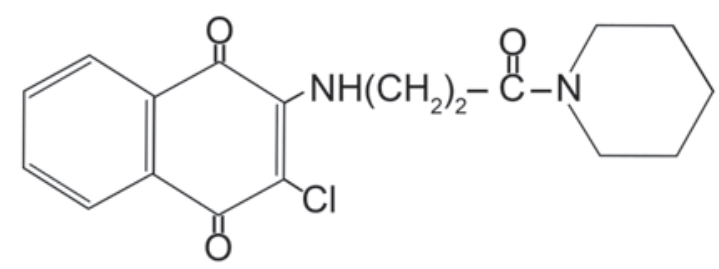

2-chloro-3-(3-oxo-3-(piperidine-1-yl)propylamine)-1,4-naphthoquinone (FO-1)

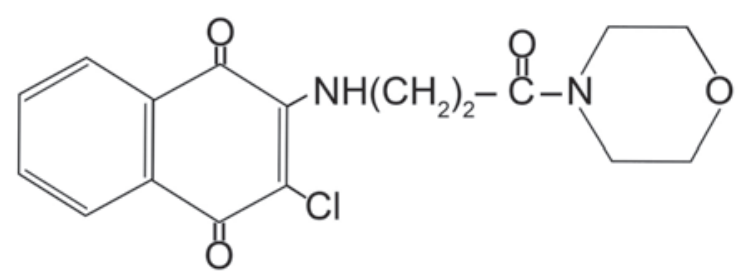

2-chloro-3-(3-(morpholine-4-yl)-3-oxopropylamine)-1,4-naphthoquinone (FO-2)

Fig. 1. Structures of 1,4-naphthoquinone derivatives

Combination of quinoid and heterocyclic fragments in one molecule is a promising step in development of new biologically active compounds with a potent physiological effect [6]. Morpholine and piperidinyl fragments are widely used in pharmaceutical preparations with anti-bacterial, anti-inflammatory, analgesic, anti-tumor effect and can act as protease inhibitors [6]. Moreover, they are powerful and selective ligands for a number of different biological purposes and may be involved in donoracceptor interactions. Given the specific properties of the 1,4-naphthoquinone amide derivatives, synthesis of new compounds containing aliphatic chains of various compositions and their biological screening for development of efficient low-toxic drugs are of particular interest [1, 2].

Our previous studies on loach embryos and larvae [7] showed that 1,4-naphthoquinone amide derivatives FO-1 (Mr 346) and FO-2 (Mr 348) at concentration of $10^{-3}-10^{-5} \mathrm{M}$ exhibit fetotoxic effect causing development delay and abnormalities that indicate an ability of the studied naphthoquinone derivatives to penetrate pervitelline space and blastomeres plasma membrane. Amide derivatives of 1,4-naphthoquinone (FO-1, FO-2) cause damage to integrity of the cytoplasm membrane, the release of intracellular components into incubation medium and, ultimately, embryos death. In survived larvae changes in the tail section (it was shorter compared with intact larvae), and a slight increase in head size were observed. Larvae were inactive; some of them demonstrated motor-incoordination and had pericardial edema. However, abnormalities were not observed in loach embryos and larvae under their development in the medium containing FO-1 and FO-2 at concentrations of $10^{-6}$ and $10^{-7} \mathrm{M}$.

A detailed study of the effect of 2-chloro-3-hydroxy-1,4-naphthoquinone ( $\mathrm{Mr} 211$ ) and its derivatives FO-1, FO-2 in vitro on prooxidant/antioxidant systems of loach Misgurnus fossilis L. embryos at various stages of early embryogenesis is relevant since it enables us to understand the mechanisms of biological effects of these compounds on cells.

\section{Materials and Methods}

The studied objects were embryos of freshwater bony fish loach Misgurnus fossilis L. (Phylum Chordata, Class - Actinopterygii, Order - Cypriniformes, Family - Cobitidae, Genus - Misgurnus). It is known that the embryo of Misgurnus fosslis L. during early embryogenesis is an appropriate test system to study the effect of various pharmacological and chemical factors on living organisms $[8,9]$. Short duration of embryogenesis, ease of obtaining sexual products and simplicity of keeping this fish in laboratory are the main criteria for its use as a research object.

All experiments with loach were performed in accordance with the rules and regulations The European Convention for the protection of vertebrate animals used for experimental and other scientific purposes (Strasbourg, 1986).

The average loach body length was $19.7 \pm 0.9 \mathrm{~cm}$. The fish were acclimated for 7 days before the experiment in a water tank. Fertilization and embryos obtaining were carried out using standard methods [7-9].

Ovulation was stimulated by administration of chorionic gonadotropin (500 units) to loach females. The eggs were obtained $36 \mathrm{~h}$ after stimulation and fertilized in Petri dishes by sperm suspension $[7,8]$. Testes were excised from the abdominal cavity of decapitated males. 5-10 min after fertilization, 
washed zygotes were incubated in Goltfreter saline solution $\left(20-22^{\circ} \mathrm{C}\right)[8,9]$. The investigation was carried out at 60, 150, 210, 270 and 330 min after egg cells fertilization. We used embryos that correspond to: first cleavage of zygote ( 2 blastomeres), fourth (16 blastomeres), sixth (64 blastomeres), eighth (256 blastomeres) and tenth (1024 blastomeres). Selected stages of embryogenesis correspond to the $1 \mathrm{~h}$ interval in development (between 16 blastomeres, 64 blastomeres, 256 blastomeres and 1024 blastomeres). During following stages a desynchronisation of embryonic cells division occurs, that is why the stages beyond 1024 blastomeres were not examined.

Loach embryos at various stages of development were homogenized in Goltfreter solution using Potter-Elvehjem homogenizer. Each homogenate sample of $1 \mathrm{ml}$ was frozen at $-20^{\circ} \mathrm{C}$ and then used in the experiments. At the beginning of the study, 2-chloro-3-hydroxy-1,4-naphthoquinone, FO-1, FO-2 were added to each sample to a final concentration of $10^{-7}, 10^{-5}, 10^{-3} \mathrm{M}$, respectively. The protein content in each sample was determined by Lowry assay [10].

We measured intensity of lipid peroxidation by assessment of TBA-reactive substances (TBARS) content as described in [11] as well as activities of antioxidant enzymes such as superoxide dismutase (SOD) [12] and catalase (CAT) [13].

The following reagents were used in the study: Tris-HCl (Ambion, USA), EDTA (Invitrogen, USA), $\mathrm{N}, \mathrm{N}, \mathrm{N}^{\prime}, \mathrm{N}^{\prime}$-tetramethylethylenediamine (Fluka, Germany). All other reagents were of domestic production (Sfera Sim, Ukraine) puriss or analytical grade.

The experimental data were statistically processed using Microsoft Excel-2007 Software. The significance of the difference between the mean values was evaluated using Student's $t$-test. The difference was considered statistically significant at $P<0.05$.

The normality of distribution was analyzed using the Kolmogorov-Smirnov test criteria and the SPSS Statistics 17 software.

Two-factor analysis of variance was performed using Excel-2007 software for statistical analysis to assess the contribution of the stage of embryogenesis $(60,150,210,270,330 \mathrm{~min})$ and the studied 1,4-naphthoquinone derivatives to the effect on the TBARS content and SOD and CAT activities.

\section{Results and Discussions}

It was found that the TBARS content in loach embryos at all studied stages of development under the effect of 2-chloro-3-hydroxy-1,4-naphthoquinone, FO-1, FO-2 decreased in a dose-dependent manner (Table 1). It should be noted that the administration of these compounds at low concentrations $\left(10^{-7} \mathrm{M}\right)$ led to a decrease in the content of lipid peroxidation byproducts, on the average by $51 \%$, whereas at high concentrations $\left(10^{-3} \mathrm{M}\right)-$ by $80 \%$.

It was found that the effects of FO-1 and FO-2 on the intensity of lipid peroxidation in loach embryos at the studied development stages were similar to the effect of 2-chloro-3-hydroxy-1,4-naphthoquinone.

The observed inhibitory effect of the quinone compounds on lipid peroxidation are consistent with the literature data, however the mechanism of this action is still not fully understood [14-16]. Such disruption to the normal course of oxidative processes can lead to morphological and functional changes in cells $[4,8]$.

It is known that high biological activities of ROS and peroxidation products require continuous functioning of specific mechanisms of antioxidant defense (AOD), the main components of which are antioxidant enzymes. The latter along with non-enzyme antioxidants perform cytoprotective function restraining prooxidant process at all stages (beginning from the ROS formation). The weakening of any AOD part due to interdependence of all its components, or compensatory mechanism disorders can lead to oxidative stress [17].

To investigate the prooxidant-antioxidant cell status under the effect of 2-chloro-3-hydroxy-1,4naphthoquinone and 1,4-naphthoquinone derivatives we studied activity of key enzymes of the loach embryos antioxidant system, namely SOD and CAT.

We observed a significant increase in SOD activity (Table 2). The intensity of SOD at the studied loach embryogenesis stages increased more significantly at high concentrations of 2-chloro-3-hydroxy-1,4-naphthoquinone, FO-1, FO-2 (in the range of 9-82-fold). This enzyme is known to regulate the peroxidation processes at the stage of initiation by catalyzing dismutation of superoxide anion radicals that lead to hydrogen peroxide and molecular oxygen formation.

It was found that 2-chloro-3-hydroxy-1,4-naphthoquinone and FO-1 induced sharp increase in the SOD activity at late studied stages of loach embryo development 256 blastomeres (on the average 26fold) and 1024 blastomeres (on the average 54-fold). FO-2 administration led to increase (14-fold) in this 
Ta b le 1. The content of TBA-reactive substances ( $\mu \mathrm{mol} / \mathrm{mg}$ protein) in loach embryos at different stages of development under the effect of 1,4-naphthoquinone derivatives $(M \pm m, n=10)$

\begin{tabular}{|l|c|c|c|c|c|c|}
\hline \multirow{2}{*}{ Compound } & \multirow{2}{*}{$\begin{array}{c}\text { Concent- } \\
\text { ration, }\end{array}$} & \multicolumn{5}{c|}{ Stages of early embryogenesis (number of blastomeres) } \\
\cline { 3 - 7 } & & 2 & 16 & 64 & 256 & 1024 \\
\hline \multicolumn{2}{|c|}{ Control } & $0.513 \pm 0.0322$ & $0.553 \pm 0.007$ & $0.501 \pm 0.041$ & $0.543 \pm 0.026$ & $0.922 \pm 0.041$ \\
\hline \multirow{2}{*}{$\begin{array}{l}\text { 2-chloro-3- } \\
\text { hydroxy-1,4- } \\
\text { naphthoquinone }\end{array}$} & $10^{-7}$ & $0.295 \pm 0.002$ & $0.411 \pm 0.001$ & $0.219 \pm 0.001$ & $0.253 \pm 0.004$ & $0.366 \pm 0.007$ \\
\cline { 2 - 7 } & $10^{-5}$ & $0.199 \pm 0.002$ & $0.178 \pm 0.031$ & $0.121 \pm 0.002$ & $0.125 \pm 0.001$ & $0.240 \pm 0.004$ \\
\cline { 2 - 7 } & $10^{-3}$ & $0.150 \pm 0.001$ & $0.159 \pm 0.001$ & $0.108 \pm 0.002$ & $0.118 \pm 0.001$ & $0.188 \pm 0.002$ \\
\hline \multirow{3}{*}{ FO-1 } & $10^{-7}$ & $0.306 \pm 0.001$ & $0.358 \pm 0.002$ & $0.298 \pm 0.001$ & $0.210 \pm 0.001$ & $0.334 \pm 0.001$ \\
\cline { 2 - 7 } & $10^{-5}$ & $0.108 \pm 0.001$ & $0.16 \pm 0.003$ & $0.144 \pm 0.002$ & $0.134 \pm 0.001$ & $0.191 \pm 0.003$ \\
\cline { 2 - 7 } & $10^{-3}$ & $0.089 \pm 0.001$ & $0.068 \pm 0.001$ & $0.105 \pm 0.002$ & $0.112 \pm 0.001$ & $0.139 \pm 0.004$ \\
\hline \multirow{3}{*}{ FO-2 } & $10^{-7}$ & $0.235 \pm 0.001$ & $0.230 \pm 0.003$ & $0.281 \pm 0.001$ & $0.200 \pm 0.004$ & $0.269 \pm 0.001$ \\
\cline { 2 - 7 } & $10^{-5}$ & $0.170 \pm 0.001$ & $0.145 \pm 0.001$ & $0.140 \pm 0.003$ & $0.137 \pm 0.002$ & $0.192 \pm 0.001$ \\
\cline { 2 - 7 } & $10^{-3}$ & $0.153 \pm 0.003$ & $0.073 \pm 0.001$ & $0.072 \pm 0.001$ & $0.116 \pm 0.001$ & $0.140 \pm 0.001$ \\
\hline
\end{tabular}

Here and in Table 2 the difference is statistically significant with respect to control $(P<0.001)$

Ta ble 2. The activity of superoxide dismutase (activity unit/min $\mathrm{mg}$ protein) in loach embryos under the effect of 1,4-naphthoquinone derivatives $(M \pm m, n=10)$

\begin{tabular}{|l|c|c|c|c|c|c|}
\hline \multirow{2}{*}{ Compound } & \multirow{2}{*}{$\begin{array}{c}\text { Concent- } \\
\text { ration, M }\end{array}$} & \multicolumn{5}{c|}{ Stages of early embryogenesis (number of blastomeres) } \\
\cline { 3 - 7 } & & 2 & 16 & 64 & 256 & 1024 \\
\hline \multicolumn{2}{|c|}{ Control } & $481 \pm 29$ & $577 \pm 20$ & $364 \pm 20$ & $276 \pm 6$ & $135 \pm 6$ \\
\hline \multirow{2}{*}{$\begin{array}{l}\text { 2-chloro-3- } \\
\text { hydroxy-1,4- } \\
\text { naphthoquinone }\end{array}$} & $10^{-7}$ & $3835 \pm 263$ & $3753 \pm 219$ & $4098 \pm 71$ & $4890 \pm 129$ & $4932 \pm 51$ \\
\cline { 2 - 7 } & $10^{-5}$ & $4862 \pm 231$ & $3977 \pm 348$ & $7772 \pm 122$ & $6320 \pm 236$ & $8257 \pm 325$ \\
\cline { 2 - 7 } & $10^{-3}$ & $6638 \pm 389$ & $5255 \pm 224$ & $9668 \pm 270$ & $6977 \pm 51$ & $9066 \pm 490$ \\
\hline \multirow{3}{*}{ FO-1 } & $10^{-7}$ & $2862 \pm 617$ & $5236 \pm 262$ & $1629 \pm 119$ & $5773 \pm 245$ & $2998 \pm 136$ \\
\cline { 2 - 7 } & $10^{-5}$ & $4130 \pm 369$ & $7930 \pm 87$ & $3114 \pm 181$ & $8395 \pm 947$ & $7671 \pm 417$ \\
\cline { 2 - 7 } & $10^{-3}$ & $5608 \pm 225$ & $8514 \pm 112$ & $4971 \pm 233$ & $10270 \pm 668$ & $11007 \pm 304$ \\
\hline \multirow{3}{*}{ FO-2 } & $10^{-7}$ & $5863 \pm 284$ & $7560 \pm 571$ & $6133 \pm 812$ & $8089 \pm 74$ & $8523 \pm 434$ \\
\cline { 2 - 7 } & $10^{-5}$ & $6893 \pm 114$ & $8103 \pm 166$ & $6799 \pm 205$ & $9294 \pm 142$ & $10733 \pm 1789$ \\
\cline { 2 - 7 } & $10^{-3}$ & $8162 \pm 46$ & $9112 \pm 124$ & $7522 \pm 460$ & $9294 \pm 680$ & $11111 \pm 89$ \\
\hline
\end{tabular}

enzyme activity compared to the control already at the 2- and 16-cell stages of embryo development. At the 64-cell stage SOD activity increased 19-fold; at the stage 256 blastomeres - 32-fold, 1024 blastomeres - 75-fold.

It is known that quinone compounds, which are derivatives of 1,4-naphthoquinone, effectively interact with oxygen radicals including the fatty acid peroxide radicals $\mathrm{RO}_{2}$ : It is known that ubiquinol (the reduced form of ubiquinone) in mitochondria not only inactivates lipid radicals and inhibits lipid peroxidation but also protects DNA and proteins from oxidative damage and inhibits tyrosine residue nitration induced by peroxynitrite [18]. This explains the fact that the TBARS content in loach embryos decreased under the effect of 1,4-naphthoquinone derivatives.

It is known from the literature that naphthoquinone reduction in cells can occur due to NADH or $\mathrm{NAD}(\mathrm{P}) \mathrm{H}$ and is catalyzed by some of flavoprotein enzymes. In particular, the quinone moiety can be reduced to the corresponding semiquinone $[2,4]$ which, in turn, can easily give an electron to oxygen to form superoxide anion and further generate hydroxyl and hydroperoxyl radicals [4]. Quinones can be also reduced into hydroquinone by two electrons 


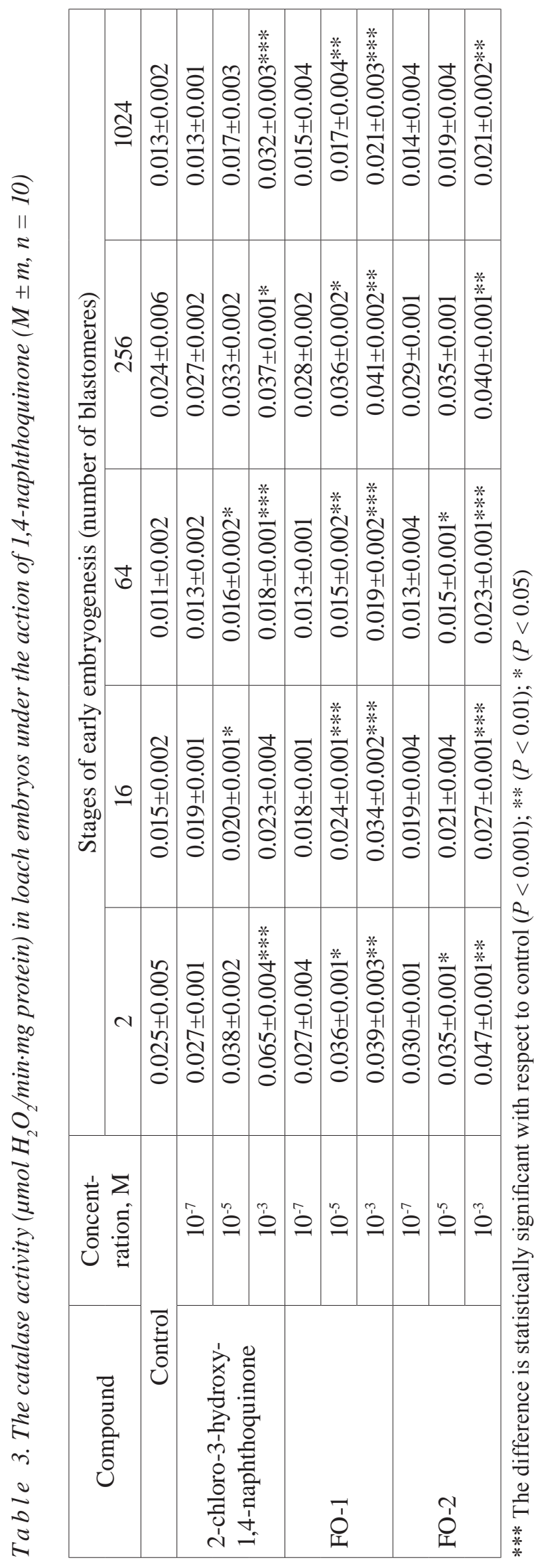

that is catalyzed by $\mathrm{NAD}(\mathrm{P}) \mathrm{H}$ : quinone oxidoreductase-1 (NQO-1, DT-diaphorase) [4, 16]. Semiquinone or hydroquinone, formed after reduction of the quinone moiety, can interact with various biomacromolecules and exhibit higher activity than the parent pharmacological quinone [2, 4]. Increase in SOD activity under the action of 2-chloro-3-hydroxy-1,4naphthoquinone, FO-1, FO-2 indicates formation of a large amount of superoxide anion radical $\mathrm{O}_{2}^{-}$(which this enzyme inactivates) in loach embryo cells at the studied stages of development. A significant increase in SOD activity supports the view that naphthoquinones can act simultaneously as pro-oxidants and antioxidants [18].

When studying the effect of 1,4-naphthoquinone on activity of CAT, which functions in a cell together with SOD, preventing accumulation of hydrogen peroxide and formation of highly reactive hydroxyl radicals, we observed an increase in the CAT activity during the test time of loach embryos development (Table 3), however an increase in the CAT activity does not correlate with an increase in the activity of SOD (the work of which is higher by several orders). It is known that hydrogen peroxide can be detoxified by another antioxidant enzyme, in particular glutathione peroxidase.

It should be noted that the increase of catalase activity in loach embryos is more pronounced at high studied concentrations of 1,4-naphthoquinone derivatives. The increase in CAT activity at naphthoquinone derivatives concentration of $10^{-7} \mathrm{M}$ was not statistically significant.

The observed antioxidant enzymes activation at the action of the studied compounds may be a result of excessive ROS production [15] due to unstable metabolite such as semiquinone that transfers electrons to molecular oxygen, thereby generating superoxide anion radical. These data are consistent with the literature data which have demonstrated that the naphthoquinone derivatives are able to increase the SOD and CAT activities in the rat liver and other organs [19, 20].

To assess the effect of the development time and studied compounds on the intensity of lipid peroxidation and activity of AOD enzymes during loach embryogenesis we performed two-factor analysis of variance (Fig. 2-4). The investigation of the effect of the time factor and 2-chloro-3-hydroxy-1,4-naphthoquinone on the TBARS content revealed that the effect of the quinone derivative $(80.2 \%, P<0.01)$ predominates over the effect of other factor (11\%) and 


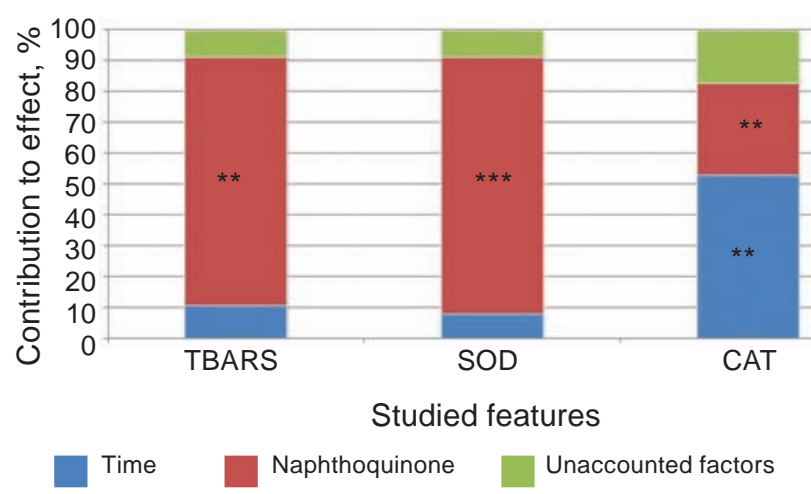

Fig. 2. The results of analysis of variance of the effect of development time and 2-chloro-3-hydroxy-1,4naphthoquinone on features of prooxidant-antioxidant homeostasis during loach embryogenesis. *** The difference is statistically significant with respect to control $(P<0.001) ; * *(P<0.01)$

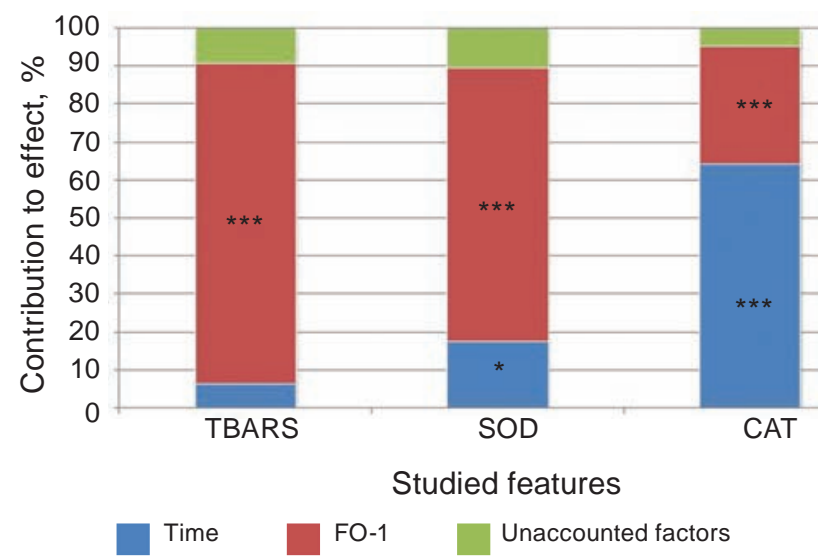

Fig. 3. The results of analysis of variance for the effect of development time and the amide derivative FO-1 on features of prooxidant-antioxidant homeostasis during loach embryogenesis. *** The difference is statistically significant with respect to control $(P<0.001)$;** $(P<0.01)$; $*(P<0.05)$

unaccounted factors. The effect of the studied substance on the SOD activity was $82.3 \%(P<0.001)$, the effect of the development time $-8 \%$. It is important to note that the effect of all studied compounds on the CAT activity was minimal, whereas the time of embryo development affected the CAT activity significantly.

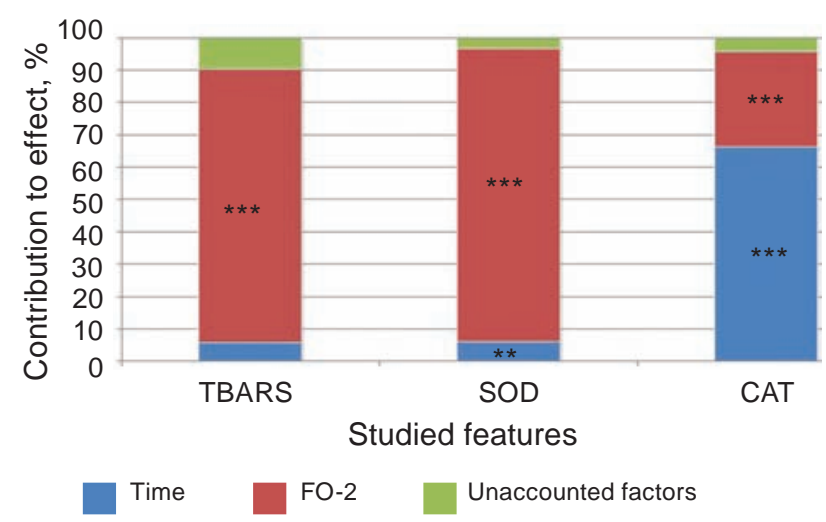

Fig. 4. The results of analysis of variance for the effect of development time and the amide derivative FO-2 on features of prooxidant-antioxidant homeostasis during loach embryogenesis. *** The difference is statistically significant with respect to control $(P<0.001) ; * *(P<0.01) ; *(P<0.05)$

Performing the analysis of variance it was found that the amide derivatives FO-1 and FO-2 exhibit a significant effect on the TBARS content and SOD activity. The contribution of FO-1 to the effect on the TBARS content and SOD activity were 84.2\% $(P<0.001)$ and $72 \%(P<0.001)$, respectively. The values of the FO-2 effect on the TBARS content and SOD activity were $84.6 \%(P<0.001)$ and $91 \%$ $(P<0.001)$, respectively. The obtained data allows us to conclude that the test compounds directly affect the TBARS formation and SOD activity. At the same time, the catalase activity is more influenced by time of loach embryo development, however a minor effect of 1,4-naphthoquinone is also reliably evident.

Thus, introduction of the studied compounds into incubation medium leads to a decrease in the content of lipid peroxidation products. Furthermore, under their effect the activities of superoxide dismutase and catalase increase in loach embryo cells during early embryogenesis. The results of two-factor analysis of variance demonstrate that 2-chloro3-hydroxy-1,4-naphthoquinone and amide derivatives of 1,4-naphthoquinone (FO-1 and FO-2) have more significant effect on the TBARS content and superoxide dismutase activity. Still, time of loach embryos development has the dominating influence on the catalase activity compared with the studied 1,4-naphthoquinone derivatives . 


\section{ПРООКСИДАНТНО- \\ АНТИОКСИДАНТНИЙ СТАН \\ ЗАРОДКІВ В'ЮНА ЗА ВПЛИВУ \\ АМІДНИХ ПОХІДНИХ 1,4-НАФТОХІНОНУ}

\author{
А. О. Безкоровайний ${ }^{1,2}$, А. Р. Зинь \\ Н. П. Гарасим ${ }^{1}$ Ю. Т. Лень ${ }^{2,3}$, \\ О. М. Фігурка
}

\author{
${ }^{1}$ Львівський національний університет \\ імені Івана Франка, Україна; \\ ${ }^{2}$ Львівський науково-дослідний експертно- \\ криміналістичний центр МВС України; \\ ${ }^{3}$ Національний університет «Львівська \\ політехніка», Україна; \\ e-mail: andriy.bezkorovajnyj@gmail.com
}

Механізми порушень функціонування клітин, індуковані амідними похідними 1,4-нафтохінону залишаються недостатньо з'ясованими. У роботі досліджували особливості впливу цих похідних на про-/антиоксидантний гомеостаз зародків в'юна Misgurnus fossilis L. в період раннього ембріогенезу. Вивчали вплив 2-хлоро-3-гідрокси-1,4-нафтохінону, 2-хлоро-3(3-оксо-3-(піпередин-1-іл)пропіламіно)-1,4-нафтохінону (ФО-1), 2-хлоро-3-(3-(морфолін-4-іл)3-оксопропіламіно)-1,4-нафтохінону (ФО-2) в концентраціях $10^{-3}, 10^{-5}, 10^{-7} \mathrm{M}$ на вміст вторинних продуктів пероксидного окислення ліпідів (ТБК-активних продуктів), активність супероксиддисмутази і каталази зародків в'юна. Встановлено, що вміст ТБК-активних продуктів у зародкових клітинах за впливу амідних похідних 1,4-нафтохінону і вихідної сполуки їхнього синтезу (2-хлоро-3-гідрокси-1,4-нафтохінону) дозозалежно знижувався впродовж досліджуваного періоду, тоді як активність супероксиддисмутази та каталази, порівняно 3 контролем зростала. Результати двофакторного дисперсійного аналізу свідчать про те, що переважно на вміст ТБК-активних продуктів і активність супероксиддисмутази впливали 2-хлоро-3-гідрокси-1,4нафтохінон та амідні похідні 1,4-нафтохінону (ФО-1 та ФО-2). Проте на роботу каталази значну дію мав час розвитку зародків в'юна у порівнянні 3 досліджуваними похідними 1,4-нафтохінону.

К л ю ч о в і с ло в а: зародки в’юна, амідні похідні 1,4-нафтохінону, пероксидне окислення ліпідів, супероксиддисмутаза, каталаза.
ПРООКСИДАНТНО-

АНТИОКСИДАНТНОЕ СОСТОЯНИЕ

ЗАРОДЫШЕЙ ВЬЮНА ПОД

ВЛИЯНИЕМ АМИДНЫХ

ПРОИЗВОДНЫХ 1,4-НАФТОХИНОНА

А. О. Безкоровайныйй, А. Р. Зынь
Н. П. Гарасим
О. Ю. Т. Лень
О., М. Фигурка

${ }^{1}$ Львовский национальный университет имени Ивана Франко, Украина;

${ }^{2}$ Львовский научно-исследовательский экспертнокриминалистический центр МВД Украины;

${ }^{3}$ Национальный университет «Львовская политехника», Украина;

e-mail: andriy.bezkorovajnyj@gmail.com

Механизмы нарушений функционирования клеток, индуцированные амидными производными 1,4-нафтохинона остаются недостаточно выясненными. В работе исследовали особенности влияния этих производных на про-/антиоксидантный гомеостаз зародышей вьюна Misgurnus fossilis L. в период раннего эмбриогенеза. Изучали влияние 2-хлоро-3гидрокси-1,4-нафтохинона, 2-хлоро-3-(3-оксо-3(пипередин-1-ил)пропиламина)-1,4-нафтохинона (ФО-1), 2-хлоро-3-(3-морфолин-4-ил)-3-оксопропиламина)-1,4-нафтохинона (ФО-2) в концентрациях $10^{-3}, 10^{-5}, 10^{-7} \mathrm{M}$ на содержание вторичных продуктов пероксидного окисления липидов (ТБК-активных продуктов), активность супероксиддисмутазы и каталазы зародышей вьюна. Показано, что содержание ТБК-активных продуктов в зародышевых клетках при воздействии амидных производных 1,4-нафтохинона и исходного соединения их синтеза (2-хлоро-3гидрокси-1,4-нафтохинона) дозозависимо снижалось на протяжении исследуемого периода, тогда как активность супероксиддисмутазы и каталазы по сравнению с контролем возрастала. Результаты двухфакторного дисперсионного анализа свидетельствуют о том, что преобладающее влияние на содержание ТБК-активных продуктов и активность супероксиддисмутазы оказывали 2-хлоро-3-гидрокси-1,4-нафтохинон и амидные производные 1,4-нафтохинона (ФО-1 и ФО-2). При этом на работу каталазы значительное воздействие имело время развития зародышей вьюна по сравнению с исследуемыми производными 1,4-нафтохинона. 
Ключевы е слова: зародыши вьюна, амидные производные 1,4-нафтохинона, пероксидное окисление липидов, супероксиддисмутаза, каталаза.

\section{References}

1. Kongkathip B, Akkarasamiyo S, Hasitapan K, Sittikul P, Boonyalai N, Kongkathip N. Synthesis of novel naphthoquinone aliphatic amides and esters and their anticancer evaluation. Eur J Med Chem. 2013; 60: 271-284.

2. Wellington KW. Understanding cancer and the anticancer activities of naphthoquinones. RSC Advances. 2015; 5(26): 20309-20338.

3. Pradidphol N, Kongkathip N, Sittikul P, Boonyalai N, Kongkathip B. First synthesis and anticancer activity of novel naphthoquinone amides. Eur J Med Chem. 2012; 49: 253-270.

4. Klotz LO, Hou X, Jacob C. 1,4-Naphthoquinones: from oxidative damage to cellular and intercellular signaling. Molecules. 2014; 19(9): 1490214918.

5. Kumagai Y, Shinkai Y, Miura T, Cho AK. The chemical biology of naphthoquinones and its environmental implications. Annu Rev Pharmacol Toxicol. 2012; 52: 221-247.

6. Al-Ghorbani M, Bushra Begum A, Zabiulla, Mamatha SV, Khanum Shaukath Ara. Piperazine and morpholine: synthetic preview and pharmaceutical applications. Res J Pharm Technol. 2015; 8(5): 611-628.

7. Bezkorovaynyj AO, Zyn AR, Harasym NP, Len JT, Figurka OM, Sanagursky DI. Effect of 1,4-naphthoquinone amide derivatives on morphological changes in loach embryos and larvae. Studia Biologica. 2015; 9(3-4): 79-88. (In Ukrainian).

8. Zyn AR, Holovchak NP, Tarnovska AV, Galan MB, Sanagursky DI. Effect of sodium hypochlorite on prooxidant and antioxidant homeostasis of loach embryos during early embryogenesis. Studia Biologica. 2012; 6(1): 6776. (In Ukrainian).

9. Sanagursky DI. Objects of Biophysics: Monograph. Lviv: Publishing Center of Ivan Franko National University of Lviv, 2008. 522 p. (In Ukrainian).
10. Lowry $\mathrm{OH}$, Rosenbrough NJ, Farr AL, Randall RJ. Protein measurement with the Folin phenol reagent. J Biol Chem. 1951; 193(1): 265275.

11. Timirbulatov RA, Seleznev EI. Method for increasing the intensity of free radical oxidation of lipid-containing components of the blood and its diagnostic significance. Lab Delo. 1981; (4): 209-211. (In Russian).

12. Kostiuk VA, Potapovich AI, Kovaleva ZhV. A simple and sensitive method of determination of superoxide dismutase activity based on the reaction of quercetin oxidation. Vopr Med Khim. 1990; 36(2): 88-91. (In Russian).

13. Korolyuk MA, Ivanova LI, Mayorova IG, Tokarev VE. A method of determining catalase activity. Lab Delo. 1988; (1): 16-19. (In Russian).

14. Dubin M, Fernandez Villamil SH, Stoppani AO. Inhibition of microsomal lipid peroxidation and cytochrome P-450-catalyzed reactions by beta-lapachone and related naphthoquinones. Biochem Pharmacol. 1990; 39(7): 1151-1160.

15. Elingold I, Taboas MI, Casanova MB, Galleano M, Silva RS, Menna-Barreto RF, Ventura Pinto A, de Castro SL, Costa LE, Dubin M. Mechanism of action of novel naphthofuranquinones on rat liver microsomal peroxidation. Chem Biol Interact. 2009; 182(2-3): 213-219.

16. Kargin VI, Motovilov KA, Vyssokikh MYu, Yaguzhinsky LS. Interaction of positively charged ubiquinone analog (MitoQ10) with DT-diaphorase from liver mitochondria. Biol. Membr. 2008; 25(1): 34-40.

17. Helmut S. Oxidative Stress. Elsevier. 2013. 507 p.

18. Menshchikova EB, Lankin VZ, Bondar NK, Krugovykh NF, Trufakin VA. Oxidative stress. Prooxidants and antioxidants. M : The company "Word", 2006. 556 p. (In Russian).

19. Ollinger K, Brunmark A. Effect of hydroxy substituent position on 1,4-naphthoquinone toxicity to rat hepatocytes. J Biol Chem. 1991; 266(32): 21496-21503.

20. Pritsos CA, Aaronson LM, Pardini RS. Metabolic consequences of dietary 2,3-dichloro1,4-naphthoquinone (CNQ) in the rat. Alteration in anti-oxidant enzyme activities. Biochem Pharmacol. 1986; 35(7): 1131-1135.

Received 12.04.2016 